\title{
Musk gland seasonal development and musk secretion are regulated by the testis in muskrat (Ondatra zibethicus)
}

\author{
Tianxiang Zhang ${ }^{1 \dagger}$, Dong Peng ${ }^{1 \dagger}$, Lei Qi ${ }^{1 \dagger}$, Weixuan $\mathrm{Li}^{3+}$, Mengyuan Fan ${ }^{1}$, Jiachen Shen², Liangliang Yang ${ }^{1}$, \\ Yihua Wang ${ }^{1}$, Wenxia Wang ${ }^{1}$, Xiaolong Hu', Ruibo Cai', Ran Zhou' ', Yuting Wei', Juntong Zhou', Shuang Yang ${ }^{1}$, \\ Defu $\mathrm{Hu}^{1 *}$ and Shuqiang Liü ${ }^{1 *}$
}

\begin{abstract}
Background: The muskrat is a seasonal breeder. Males secrete musk to attract females during the breeding season. The testosterone binding to the androgen receptor (AR) in musk glands of muskrat may play an important role conducting the musk secretion process.

Methods: The musk gland, testis and blood samples of musk rats are collected in both breeding and non-breeding seasons. Some part of the samples are kept in liquid nitrogen for transcriptome analysis and Western blotting test. Some part of the samples are kept in $70 \%$ alcohol for histology experiment, blood samples are kept at $-20^{\circ} \mathrm{C}$ for the serum testosterone measurement experiment.

Results: This study demonstrates that the quantity of secreted musk, the volume of the musk glands, the diameter of the gland cells and AR expression are all higher during the breeding season than at other times $(p<0.01)$. StAR, P450scc and 3 $\beta-H S D$ expression in the Leydig cells of the testis were also higher during this season, as was serum testosterone. AR was also observed in the gland cells of two other musk-secreting animals, the musk deer and small Indian civet, in their musk glands. These results suggest that the testes and musk glands co-develop seasonally.
\end{abstract}

Conclusion: The musk glands' seasonal development and musk secretion are regulated by the testes, and testosterone plays an important role in the seasonal development of musk glands.

Keywords: Muskrat, Musk gland, Testis, AR, Seasonal development

\section{Background}

The muskrat (Ondatra zibethicus) is a medium-sized, semi-aquatic rodent animal. The muskrat is a seasonal breeder, and males secrete musk from their musk glands to attract females during the breeding season. The breeding season begins in March and ends in October, lasting 8 months. Like those produced by musk deer (Moschus berezovskii) and the small Indian civet

\footnotetext{
*Correspondence: hudefu1234567@sina.com; hudf@bjfu.edu.cn; liushuqiang@bju.edu.cn

†Tianxiang Zhang, Dong Peng, Lei Qi and Weixuan Li contributed equally to this work

${ }^{1}$ College of Nature Conservation, Beijing Forestry University,

Beijing 100083, People's Republic of China

Full list of author information is available at the end of the article
}

(Viverricula indica), the musk that male muskrats' musk glands secrete during the breeding season is not only an important pheromone for attracting females [1].

The exploration of musk secretion mechanism is important to understand the seasonal change of musk secretion. Our previous study show the testis has seasonal change in muskrat, but the relationship of musk gland and testis is not clear. Prior research has suggested that musk gland development and function might be regulated by androgens $[2,3]$ produced by the testis under the control of the hypothalamus-pituitary-testis system $[4,5]$.

Androgens mediate a wide range of developmental and physiological responses [6, 7]. Testosterone as one of the most important functional androgen hormone, which is 
mainly produced by Leydig cells in testis and binds to the androgen receptor (AR), modulating gene transcription in various cells [8]. AR is expressed not only in male and female reproductive organs, but also in non-genital tissues $[6,9,10]$.

Testosterone production in the Leydig cells is primarily mediated by the steroidogenic acute regulatory protein (StAR) [11, 12]. Cholesterol is converted to pregnenolone by the cytochrome P450 cholesterol side-chain cleavage (P450scc) enzyme [13]. Pregnenolone is next metabolized to androgens by $3 \beta$-hydroxysteroid dehydroge-

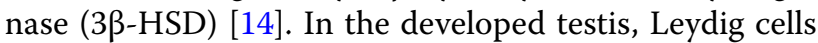
(LCs) maintain high levels of P450scc and 3 3 -HSD and, in response to luteinizing hormone (LH), rapidly synthesize StAR and testosterone [15, 16]. Prior results showed that AR is expressed in musk glands, suggesting that the testis might regulate musk gland development. Here we studied the relationship between the musk glands and the testes in different seasons, to further understand the regulation of the development and function of the former by the latter.

\section{Methods}

Animals

Three adult male muskrats were obtained in the breeding season (April) and three in the non-breeding season (November) from Xinji Jinmu Muskrat Breeding Farm, Hebei, China. The six individuals were similar in size and weight. The musk glands were collected from one adult male musk deer dead of an accident (in July) at Fengxian Musk Deer Breeding Farm, Shanxi, China. The musk gland samples of the small Indian civet were collected from one adult male individual dead of an accident (in June) at Hengshan Wild Animal Breeding Farm, Anhui, China. All animals were treated in accordance with the National Animal Welfare Legislation. All experimental procedures were carried out in accordance with the guidelines established by the Beijing Forestry University. After fixation, the musk glands and testes were kept in $70 \%$ alcohol until used for immunohistochemistry. The lengths of the muskrats' musk glands were measured and recorded. The contralateral musk gland of each muskrat was divided into small pieces and some of them were kept in liquid nitrogen for RNA-seq analysis and Western blotting test. The rest of the pieces were kept in ribonuclease inhibitor at $4{ }^{\circ} \mathrm{C}$. Blood was centrifuged at $3000 \mathrm{~g}$ for $20 \mathrm{~min}$ to separate serum from blood cells, which were collected and stored at $-20{ }^{\circ} \mathrm{C}$ until used for hormone analysis.

\section{Musk secretion weight measurement}

Ten adult male muskrats were selected for musk secretion measurement. The total musk weight in the breeding season of the selected muskrats was recorded, beginning on March 1. The measurement was made 3 times per half month. Measurements during the non-breeding season were taken in the same way, beginning on October 15.

\section{Histology}

The musk gland and testis samples were dehydrated in an ethanol series and embedded in paraffin wax. Serial sections $(4-6 \mu \mathrm{m})$ were mounted on slides coated with APES (3-aminopropyl-triethoxysilane). Some sections were stained with haematite hematoxylin (Solarbio) for observations of general histology.

\section{Immunohistochemistry}

Serial sections of musk gland were incubated with primary polyclonal antibody (200 $\mu \mathrm{g} / \mathrm{ml}, 1: 200$ dilution) against AR (Abcam) for $12 \mathrm{~h}$ at $4{ }^{\circ} \mathrm{C}$. Serial sections of testis were incubated with primary polyclonal antibody $(200 \mu \mathrm{g} / \mathrm{ml}, 1: 200$ dilution) against StAR (Santa Cruz Biotechnology), P450scc (Abcam) or 3ß-HSD (Abcam) for $12 \mathrm{~h}$ at $4{ }^{\circ} \mathrm{C}$. The sections were then incubated with a second antibody, goat anti-rabbit IgG conjugated to biotin and to peroxidase with avidin, using a rabbit ExtrAvidin staining kit (ZSGB-BIO), followed by visualizing with $0.5 \mathrm{mg}$ 3,3-diaminobenzidine (Solarbio) solution in $1 \mathrm{ml}$ of $0.05 \mathrm{M}$ Tris- $\mathrm{HCl}$ buffer, $\mathrm{pH}$ 7.6, plus $0.4 \mathrm{l} \mathrm{H}_{2} \mathrm{O}_{2}$.

\section{Western blotting}

The musk gland tissues were kept at $-80{ }^{\circ} \mathrm{C}$. The samples were from three individuals in April and another three in November. Take approximately $0.1 \mathrm{~g}$ tissue from each individuals. Homogenize the tissue in a homogenizer containing $300 \mu \mathrm{l}$ of $10 \mathrm{mg} / \mathrm{ml}$ PMSF stock and incubated on ice for $30 \mathrm{~min}$ while maintaining the temperature at $4{ }^{\circ} \mathrm{C}$ throughout all the procedures. Take $20 \mu \mathrm{l}$ protein sample mixed with $5 \mu$ l loading buffer (final concentration: $32 \mathrm{mM}$ Tris- $\mathrm{HCl}, \mathrm{pH} 6.8,12.5 \%$ glycerol (v/v), 1\% SDS, and $31 \mu \mathrm{M} \beta$-mercaptoethanol) and denature it at $100{ }^{\circ} \mathrm{C}$ for $5 \mathrm{~min}$. Separate the samples and marker (Fermentas, $10-170 \mathrm{kDa}$ ) on $12 \%$ polyacrylamide gels, and transferred onto PVDF membranes. The membranes were blocked in 5\% non-fat dry milk and incubated with primary antibodies (rabbit anti-rat AR, $200 \mu \mathrm{g} / \mathrm{ml}, 1: 2000$ dilution) at room temperature for $60 \mathrm{~min}$, washed in $0.1 \%$ Tween-20 containing buffer. Secondary incubation of the membrane was then carried out using a $1 \mathrm{mg} / \mathrm{ml}, 1: 40000$ dilution of goat anti-rabbit IgG tagged with alkaline phosphatase for $60 \mathrm{~min}$.

\section{Hormone measurements}

Serum testosterone was assayed by use of a testosterone ELISA kit (BNIBT). The operation was conducted according to the specification. 


\section{RNA isolation and reverse transcription}

The musk gland tissues were kept in RNA Fixer (Biomarker technologies, China) at $4{ }^{\circ} \mathrm{C}$. The samples were from three individuals in April and another three in November. Total RNA was isolated using Trizol reagent (Qiagen, USA) according to manufacturer recommendations. RNA of checked quality was reverse transcribed into complementary DNA (Omniscript RT Kit, Qiagen, USA) following the manufacturer's protocol.

\section{RT-PCR}

The PCR conditions were $94^{\circ} \mathrm{C}$ for $3 \mathrm{~min}$, followed by 33 cycles at $94{ }^{\circ} \mathrm{C}$ for $30 \mathrm{~s}, 55^{\circ} \mathrm{C}$ for $20 \mathrm{~s}$, and $72{ }^{\circ} \mathrm{C}$ for $20 \mathrm{~s}$ using a melting curve program (increasing the temperature from 55 to $95{ }^{\circ} \mathrm{C}$ at $0.5{ }^{\circ} \mathrm{C}$ per $10 \mathrm{~s}$ ) and continuous fluorescence measurement. The PCR primers used in this experiment were $5^{\prime}$-gagacagagtggacgggat $-3^{\prime}$ and $5^{\prime}$-ggaggttacaccaaaggg- $3^{\prime}$. Transcription of GAPDH gene was used as a reference. PCR products were electrophoresed on $1.0 \%$ agarose gels.

\section{RNA-seq analysis}

Total RNA was isolated from musk gland tissues using Trizol reagent (Qiagen, USA), the quality of RNAs was determined by gel electrophoresis and spectrophotometry. Approximately $20 \mu \mathrm{g}$ of total RNAs from two individuals in each season (April and November) was used for Illumina sequencing at Biomarker technologies (Beijing, China). All procedures for cDNA library construction were performed via the standard Illumina sample preparation protocol. Sequencing of the purified libraries were carried out on an Illumina GA-II (Illumina Inc., USA).

\section{Statistical analysis}

In this study, the statistical comparisons were made with the Student $t$ test and One-way analysis of variance.

\section{Results}

\section{Musk secretion weight comparison}

The weight of musk that the selected muskrats secreted during the breeding and non-breeding seasons was recorded and summed for the two seasons (Fig. 1a). The total weight produced in the breeding season (17.36 $\pm 1.67 \mathrm{~g}$ in March and April) was significantly higher than that in the non-breeding season $(2.16 \pm 0.40 \mathrm{~g}$ in October and November $),(\mathrm{p}<0.01)$.

The seasonal profile of musk gland and testis morphology The lengths of musk glands during the two seasons were significantly different (Fig. 1c). It is obvious that the musk gland in the breeding $(38.3 \pm 4.0 \mathrm{~mm})$ was much longer than in the non-breeding season $(15.3 \pm 6.7 \mathrm{~mm}$, $\mathrm{p}<0.01$ ). Similar changes occurred in the testis (Fig. 1b), which was much larger in the breeding $(20.6 \pm 2.5 \mathrm{~mm})$ than in the non-breeding season $(10.7 \pm 1.9 \mathrm{~mm}$, $\mathrm{p}<0.01)$. Morphological observations during the breeding and non-breeding seasons of musk glands and testis are compared in Fig. 1d, e. The seasonal differences were significant. Musk glands and testes were larger in the breeding season. The musk gland cells and epithelial cells become smaller in the non-breeding season. In the testis, the Leydig cells produce testosterone. The seminiferous tubules and Leydig cells were smaller in the non-breeding season. There were fewer developed spermatids in the non-breeding season.

Immunohistochemical expression of AR in the musk gland Androgen receptor was detected in the musk gland during the breeding and non-breeding seasons by immunohistochemistry (Fig. 2a, c), and localized mainly in the glandular cells. The positive section of breeding season was more significant. The distribution of AR in muskrat musk glands was similar to that in musk deer (Fig. 2b) and in the small Indian civet (Fig. 2d).

\section{Protein expression of AR in the musk gland}

According to the Western blotting results (Fig. 2e), the positive bands of AR were shown at $92 \mathrm{kDa}$. We considered GAPDH as a reference which were shown at $37 \mathrm{kDa}$. The comparison of AR protein level in non-breeding and breeding season is significant (Fig. 2f).

\section{Immunohistochemical detection of StAR, P450scc and $3 \beta-H S D$ in the testis}

StAR, P450scc and 3 $\beta$-HSD were detected in testis in the breeding and non-breeding seasons (Fig. 3a-f). Positive reaction for StAR, P450scc and 3 $\beta$-HSD was observed mainly in the Leydig cells in both seasons. These three factors were significantly more highly expressed in the breeding than in the non-breeding season.

The immunodetection rate was calculated as the percentage of positive Leydig cells among the total number of Leydig cells. The immunodetection rates of StAR, P450scc and $3 \beta$-HSD were all reduced in the non-breeding season (Fig. 3g).

\section{Serum testosterone concentration}

The concentrations of testosterone in the serum of muskrats in the breeding and non-breeding seasons were measured using an ELISA kit. There was a significant decrease in serum testosterone from the breeding $(1.874 \pm 0.167 \mathrm{ng} / \mathrm{ml}$ in April) to the non-breeding season $(0.198 \pm 0.0673 \mathrm{ng} / \mathrm{ml}$ in November, $\mathrm{p}<0.01)$ (Fig. 3h). 

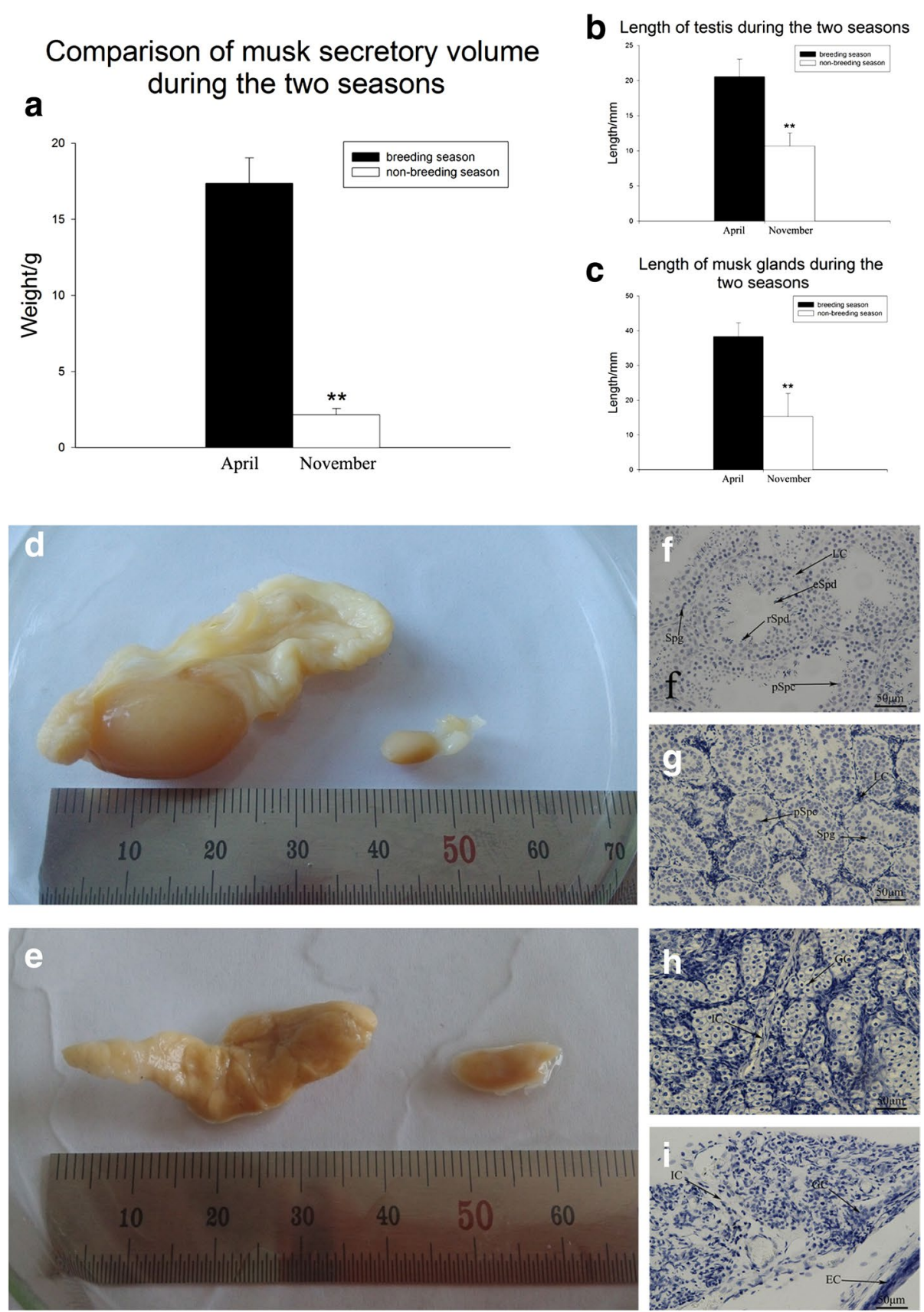

Fig. 1 Morphological difference of musk glands and testis between the two seasons. a Comparison of muskrat musk secretion weight in the breeding and non-breeding seasons. The left bar represents the total musk secretion weight of 10 muskrats in March and April (17.36 $\pm 1.67 \mathrm{~g})$. The right bar represents the total musk secretion weight of 10 muskrats in October and November $(2.16 \pm 0.40 \mathrm{~g})$. The musk secretion weight in the breeding season was obviously greater than that in the non-breeding season $(p<0.01)$. Different symbols denote statistically significant values $\left.{ }^{* *} \mathrm{p}<0.01\right)$. $\mathbf{b}$ Comparison of testis lengths in the breeding and non-breeding seasons. The left bar represents the average testis length in April $(20.6 \pm 2.5 \mathrm{~mm})$. The right bar represents the average testis length in November (10.7 $\pm 1.9 \mathrm{~mm})$. Testis length in the breeding season was significantly greater than in the non-breeding season $(p<0.01)$. c Comparison of the length of musk glands between the breeding and non-breeding seasons. The left bar represents the average length of the musk gland in April (38.3 $\pm 4.0 \mathrm{~mm})$. The right bar represents the average length of the musk gland in November $(15.3 \pm 6.7 \mathrm{~mm})$. The length of the musk gland in the breeding season was significantly greater than that in the nonbreeding season $(p<0.01)(* * p<0.01)$. d Testis morphology in the breeding and non-breeding seasons. e Musk gland morphology in the breeding and non-breeding seasons. $\mathbf{f}$ Histological structure of the muskrat testis in the breeding season. $\mathbf{g}$ Histological structure of the muskrat testis in the non-breeding season. $\mathbf{h}$ Histological structure of the muskrat musk gland in the breeding season. $\mathbf{i}$ Histological structure of the muskrat musk gland in the non-breeding season. GC glandular cells, EC epithelial cells, IC interstitial cells, LC Leydig cells, Spg spermatogonium, pSpc primary spermatocyte, $r$ Spd round spermatid, eSpd elongated spermatid 

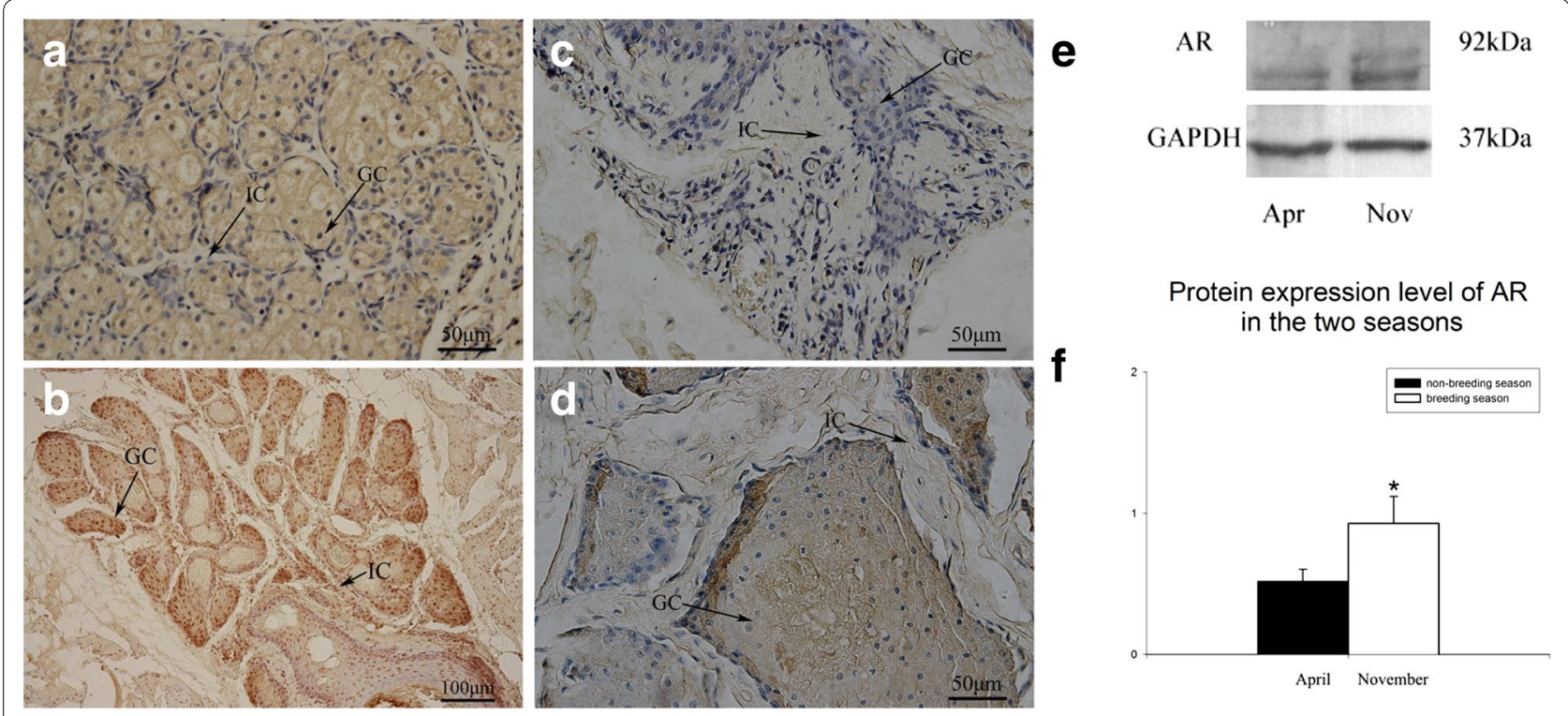

Fig. 2 Immunohistochemistry and Western-blotting results of AR expression in musk glands. a Immunolocalization of androgen receptor (AR) in muskrat musk gland in the breeding season. b Immunolocalization of AR in the musk deer (Moschus berezovskii) musk gland in the breeding season. c Immunolocalization of AR in muskrat musk gland in the non-breeding season. $\mathbf{d}$ Immunolocalization of AR in the small Indian civet (Viverricula indica) musk gland in the breeding season. GC glandular cells, IC interstitial cells. e Positive bands of AR and GAPDH. f The comparison of AR protein expression between the two seasons. The expression level was the quotient of the values of AR and GAPDH. And the value of breeding season is higher than the value in non-breeding season $(0.01<p<0.05)$

\section{AR mRNA levels in the musk gland}

The expression levels of androgen receptor were assayed in 4 musk glands from 4 individuals from the breeding and non-breeding seasons (April and November) (Fig. 4a). The expression levels of AR in the breeding were significantly higher than in the non-breeding season $(\mathrm{p}<0.01)$.

The expression of AR mRNA of breeding sample is stronger than that of non-breeding season sample (Fig. 4c). The comparison of AR mRNA level in nonbreeding and breeding season is significant (Fig. 4d).

The antibodies used in this study were all polyclonal antibodies. Comparing the RNA-sequencing analysis results with the mRNA found in NCBI gene bank, we found that the CDS of androgen receptor mRNA from muskrat had $94.4 \%$ similarity with the CDS from rat (Rattus norvegicus). It is considered that the androgen receptors of rat and muskrat has high similarity (Fig. 4b).

\section{Discussion}

The cyclic alternation between gonads growth and involution is a well-known phenomenon of seasonal breeders. The present study shows that total muskrat testis weights in the breeding were higher than in the non-breeding season (Fig. 1a). Muskrat testes were significantly larger in the breeding than in the non-breeding season (Fig. 1c). The musk glands were also significantly smaller in the non-breeding season (Fig. 1b). These seasonal changes suggest that testes and musk glands develop synchronously.

Changes in the seminiferous tubules from the breeding to the non-breeding season were also significant. It was difficult to find developed sperm cells in the seminiferous tubules of non-breeding muskrats (Fig. 1g). Similar observations have been made in other species. Findings in raccoon dogs [17], roe deer [18], horse [19], and ground squirrels [20] suggest that seasonal changes in testis size are correlated with changes in the numbers of germ cells in seasonal breeders. These results are consistent with the view that cyclical growth and involution of the testes may be universal in seasonal breeders [21]. In this study, we observed that there is also a cyclic alternation between growth and involution of the muskrat musk gland (Fig. 1h, i). This result is also in agreement with previously published work [2]. The morphological results suggest an important relationship between the muskrat musk gland and testis, simultaneously growing during the breeding season and involuting during the non-breeding season. Musk gland development and function might be regulated by the testis through testosterone produced in the Leydig cells.

Androgens have various important functions. The present study revealed that AR expression in the muskrat musk gland is higher in the breeding than in the 

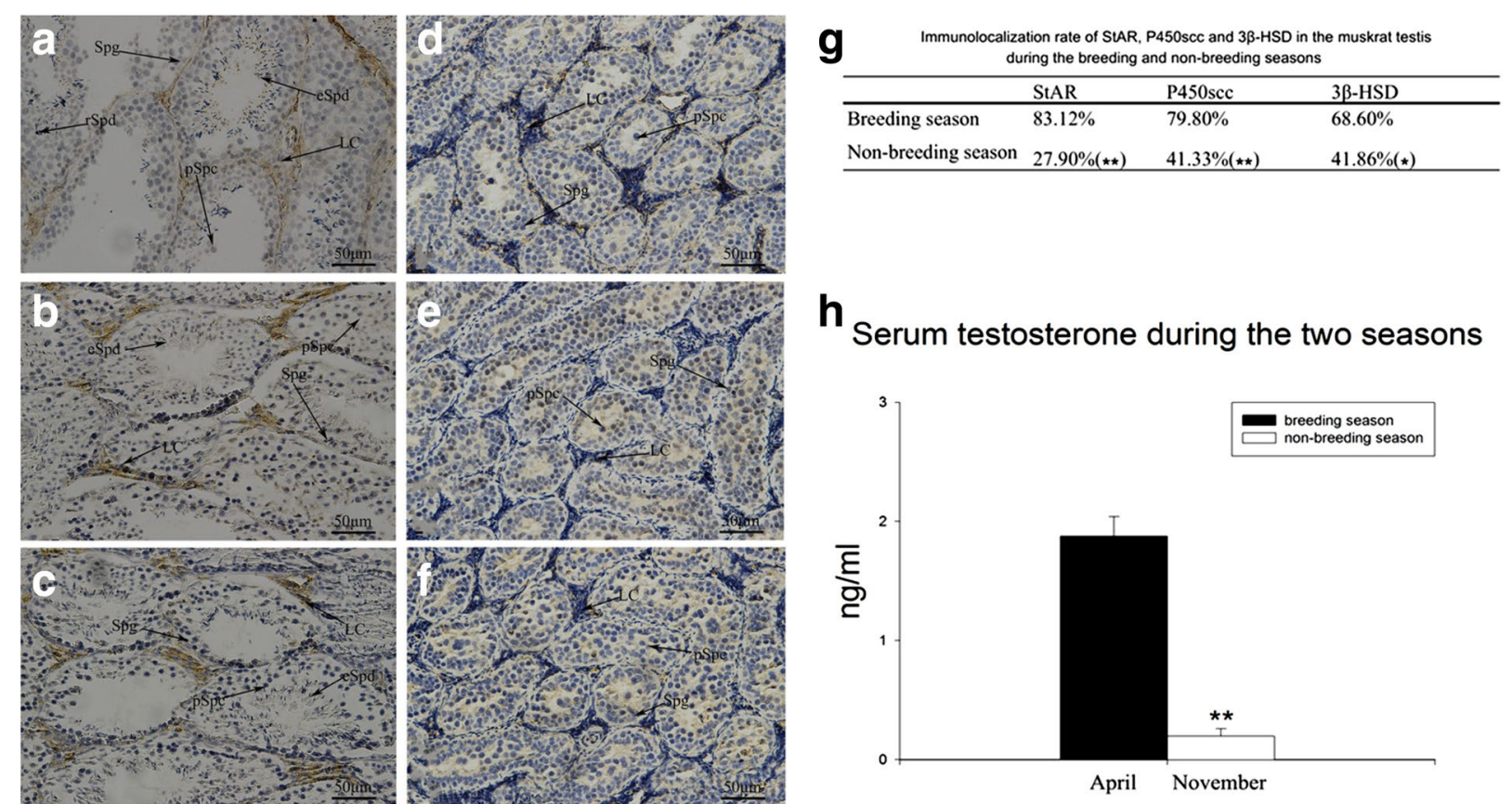

Fig. 3 Immunohistochemistry results in testis. a Immunolocalization of StAR in the testis in the breeding seasons. $\mathbf{b}$ Immunolocalization of P450scc in the testis in the breeding seasons. $\mathbf{c}$ Immunolocalization of 3 $\beta$-HSD in the testis in the breeding season. $\mathbf{d}$ Immunolocalization of StAR in the testis in the non-breeding seasons. e Immunolocalization of P450scc in the testis in the non-breeding seasons. $\mathbf{f}$ Immunolocalization of 3ß-HSD in the testis in the non-breeding season. LC Leydig cells, Spg spermatogonium, pSpc primary spermatocyte, $r$ Spd round spermatid, eSpd elongated spermatid. $\mathbf{g}$ The immunodetection rate of StAR, P450scc and 3 $\beta-H S D$ in the breeding season were all significantly higher than in the non-breeding season $\left(0.01<p<0.05 ;{ }^{* *} p<0.01\right)$. $\mathbf{h}$ Testosterone in the serum samples was assayed by ELISA three times. The left bar represents the average testosterone concentration in the breeding season $(1.874 \pm 0.167 \mathrm{ng} / \mathrm{ml})$. The right bar represents the average testosterone concentration in the non-breeding season $(0.198 \pm 0.067 \mathrm{ng} / \mathrm{ml})$. The seasonal difference between the average serum testosterone concentrations was significant $(p<0.01) .(* * p<0.01)$

non-breeding season (Fig. 2a, c). A previous study also detected AR in musk glands of muskrats [1,2]. We also found AR distributed in the musk glands of small Indian civet and musk deer (Fig. 2b, d). According to the RNAseq results AR expression in muskrat musk glands during the breeding season was significantly higher than during the non-breeding season (Fig. 4a). Additionally, AR mRNA and protein expression in the musk glands were both are higher in the breeding season (Figs. 2f, 4d). A similar trend also occurred in the serum testosterone concentration changes (Fig. 3h). These changes suggested that far more AR and androgens are needed in the breeding season to regulate musk gland development and musk production, which is in agreement with previous research $[1,2]$. Androgens mainly function via the hypothalamus-pituitary-testis system to regulate testis development. In light of our current results, we propose that androgens may have the important function of regulating the seasonal co-development of testes and musk glands. The antibody used in this study was designed to test androgen receptor expression in rat, mouse, and human tissue.
Because of the seasonal involutional changes in the testis, the volume of seminiferous tubules and Leydig cells in the non-breeding season was predicted to be smaller than that in the breeding season (Fig. 1d-i). According to the results of the hormone analysis, these changes might be regulated by seasonal changes in serum testosterone concentration (Fig. 3h). Others have conducted similar research on the function of testosterone in testis development $[22,23]$. It is clear that StAR, P450scc, and 3 $\beta$-HSD in the Leydig cells regulate testosterone production [24]. The immunohistochemical observations of the three factors in the muskrat testis in the breeding and non-breeding seasons (Fig. 3a-f) provide new evidence that the Leydig cells' regulatory function for producing androgens changes seasonally. The immunolocalization of StAR, P450scc, and 3 $\beta$-HSD differed significantly in the breeding compared with the non-breeding season, particularly in the Leydig cells. The immunohistochemical results support the observed difference in serum testosterone concentrations between the two seasons. The levels of StAR, P450scc, and $3 \beta-$ HSD as detected by immunohistochemistry were lower in the non-breeding season 


\section{Expression level of $A R$ in musk glands a during the two seasons}

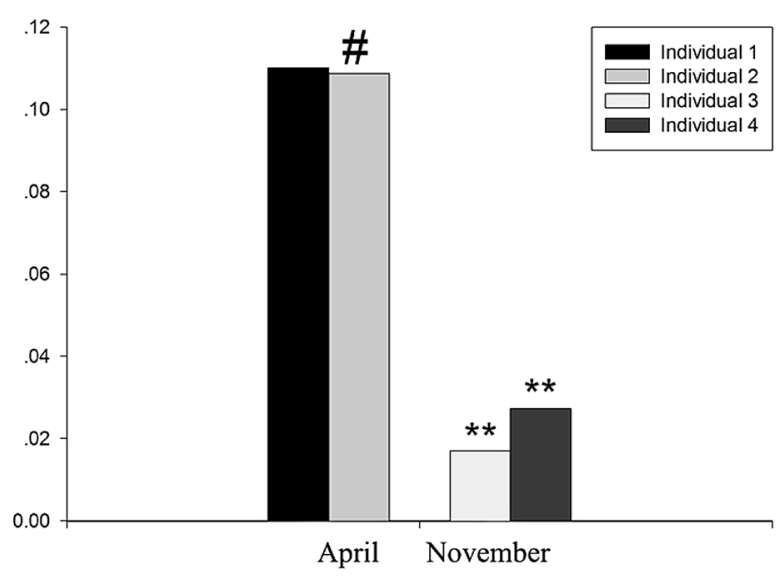

b

muskrat ATGGAGgTGCAGTTAGGACTGGGAagGGTCTACCCACGGCCCCCGTCTAAAACCTATCGAGGAGCTTTCCAGAATCTOTT

rat ATGGAGGTGCAGTIAGGGCTGGGAAGGGTCTACCCAGGGCCCCCGTCCAAGACCTATCGAGGAGCGTICCAGAATCTGII

muskrat CCAGAGGGTGCGCGAAGCGATCCAGAACCCGGGCCCCA....................................... AGCTGCTCCACGGACATT

rat CCAGAGCGTGCGGGAAGCGATCCAGAACCCGGGCCCCA.................................AGCTGCTCCGCAGACATI

muskrat AAAGACATCCTGAGCGACGCCGGCACCATGCAACTTCTTC.......................................................CAGCA

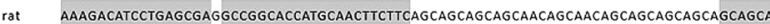

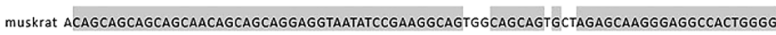

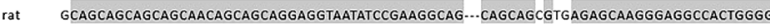

muskrat CTCCCTCTTCCTCCAAGGATAGTTACCTAGGGGGCAATTCGACCATATCTGACAGTGCCAAGGAGTIGTGTAAAGCAGTO

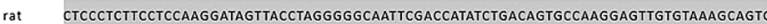

muskrat TCTGTGTCCATGGGACTGGGTGTGGAAGCATTGGAACATCTGAGTCCAGGGGAACAGCTTCGGGGAGATTGCATGTATGC

rat TCTGTGTCCATGGGGTIGGGTGTGGAAGCACTGGAACATCTGAGTCCAGGGGAGCAGCTTCGGGGCGACTGCATGTACGC

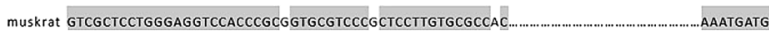

rat GTCGCTCCTGGGAGGTCCACCCGCCGTOCGTCCCACTCCTIGTGCGCCTC......................................AATGATG

muskrat GCAGAGATCATCTCTGTACAAGTGCCCAAGATCCTTTCTGgGAAAGTCAAGCCCATCTATTTCCACACACAGTGA

rat GCAGAGATCATCTCTGIGCAAGTGCCCAAGATCCTITCTGGGAAAGTCAAGCCCATCTATITCCACACACAGTGA
C

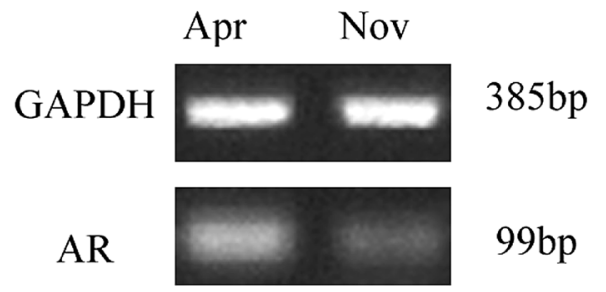

d

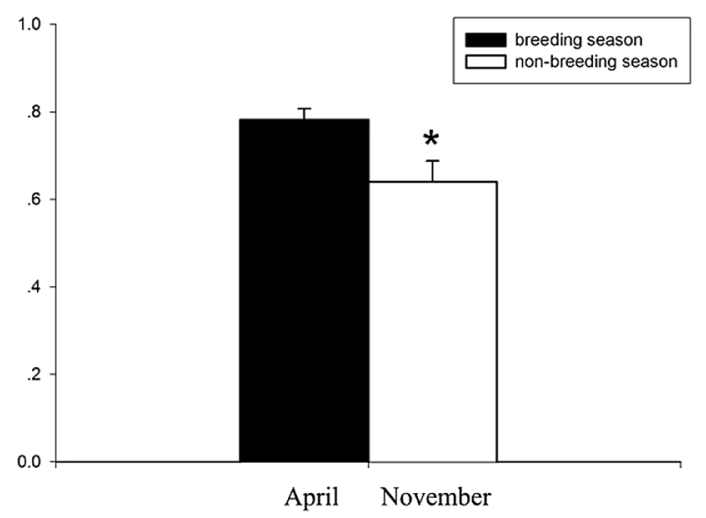

Fig. 4 RNA-seq analysis and RT-PCR results of AR in musk glands. a The expression levels of two individuals in the same season were similar $(p>0.05)$, and the expression levels of two individuals in different seasons were significantly different $(p<0.01) .\left({ }^{*} p>0.05 ;{ }^{* *} p<0.01\right)$ Individuals 1 and 2: breeding season. Individuals 3 and 4: non-breeding season. b Comparison of androgen receptor mRNA sequence of rat (Rattus norvegiCus) and muskrat (Ondatra zibethicus). (Dotted lines represents for the sequence not mentioned on purpose; straight line represents for the missing sequence during the RNA-sequencing analysis; the complete CDS results were presented in Additional file 1: Figure S1). c Positive bands of AR and GAPDH. d The comparison of AR mRNA expression between the two seasons. And the value of breeding season is higher than the value in nonbreeding season. $(0.01<p<0.05)$

(Fig. 3g), indicating that the testes' ability to produce testosterone was weaker in the non-breeding season, and this explains the seasonal difference in serum testosterone concentration.

\section{Conclusions}

The mechanism of musk gland development and musk secretion need further study. Muskrat is an appropriate model to study on the mechanism. As similar species that secrete musk, civet and musk deer are protected by law.
Muskrats can provide opportunities to conduct molecular study, while it can hardly be operated on protected animals.

The immunolocalizations of StAR, P450scc and $3 \beta$-HSD in testis express less in non-breeding season. While the immunolocations of AR in musk glands express weaker at the same time (Fig. 5). That is the reason testis' ability to synthesize testosterone and the ability of musk gland to receive testosterone are weak in non-breeding season. In summary, this study presents 

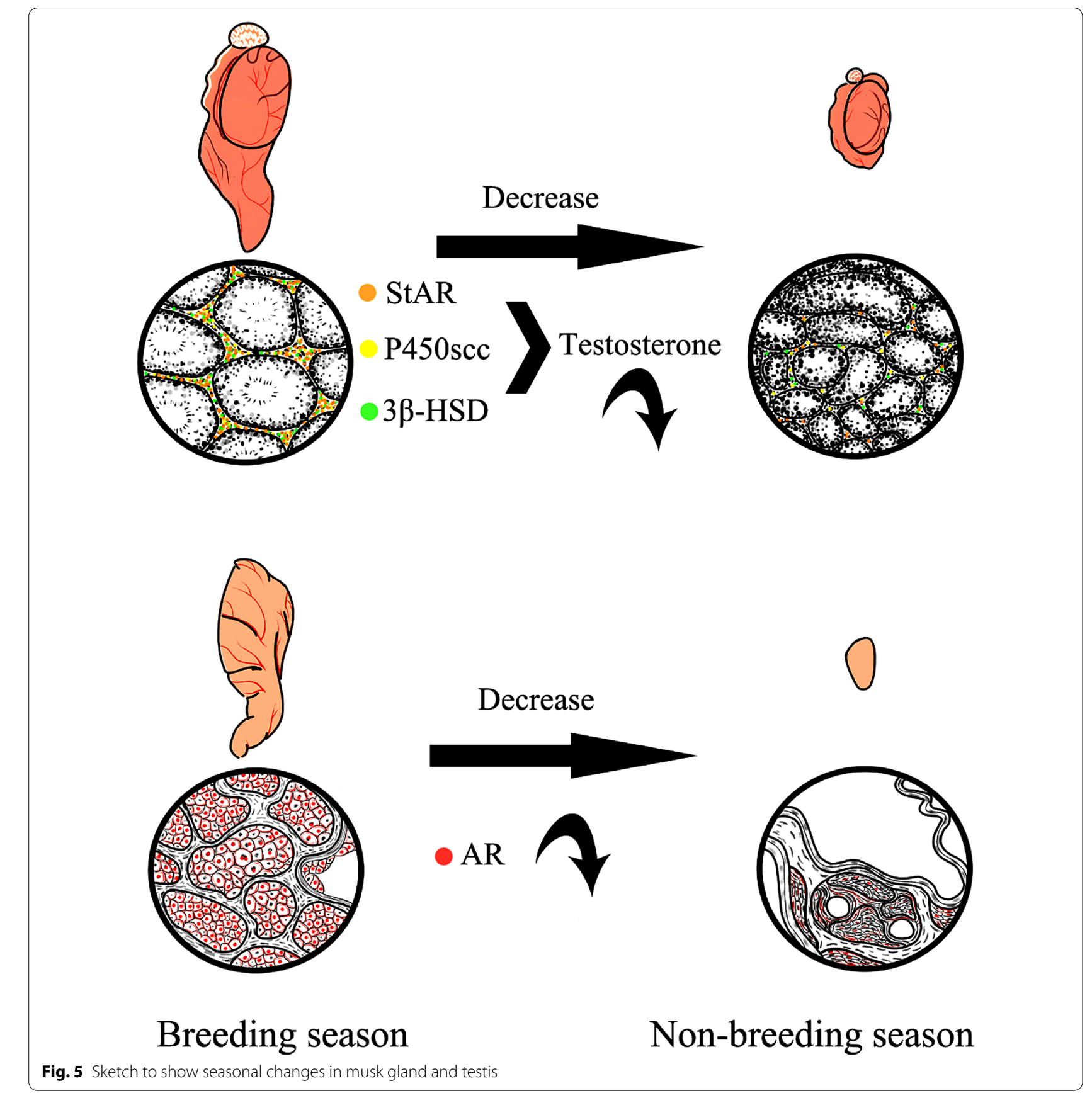

new evidence that muskrat testes and musk glands exhibit synchronous seasonal growth and involution, AR have an important role in the connection of testis and musk glands (Fig. 5).

\section{Additional file}

Additional file 1: Figure S1. CDS of androgen receptor in rat (Rattus norvegicus) and muskrat (Ondatra zibethicus).

\section{Abbreviations}

AR: androgen receptor; StAR: steroidogenic acute regulatory protein; P450scc: cytochrome P450 cholesterol side-chain cleavage; 33-HSD: 33-hydroxysteroid dehydrogenase; APES: 3-aminopropyl-triethoxysilane; ELISA: enzyme linked immunosorbent assay; RNA: ribonucleic acid.

\section{Authors' contributions}

TZ: wrote the manuscript and participated in the experiment. DP: participated in the collecting the samples and the experiment. LQ: revised the manuscript. WL: participated in the immunochemistry experiment. MF and JS: participated in the immunochemistry and RT-PCR experiment. LY, YW and WW: participated in ELISA experiment. XH and RC: participated in the Western blotting 
experiment. RZ, YW, JZ and SY: participated in the collecting tissue samples. DH: has supervised and organized the whole study experiment. SL: has supervised manuscript writing as corresponding authors. All authors read and approved the final manuscript.

\section{Author details}

${ }^{1}$ College of Nature Conservation, Beijing Forestry University, Beijing 100083, People's Republic of China. ${ }^{2}$ College of Biological Science and Technology, Beijing Forestry University, Beijing 100083, People's Republic of China. ${ }^{3}$ Zhonshan School of Medicine, Sun Yat-sen University, Guangzhou 510080, People's Republic of China.

\section{Acknowledgements}

Not applicable.

\section{Competing interests}

The authors declare that they have no competing interests.

\section{Availability of data and materials}

The information of all chemicals used in the study is available in the PubChem Substance Database.

\section{Consent for publication}

This manuscript does not contain any individual person's data.

\section{Ethics approval}

The animals used in this study were all farmed in Xinji Jinmu Muskrat Breeding Farm. And muskrats are not endangered animal. They were all treated in accordance with the National Animal Welfare Legislation.

\section{Funding}

This work was supported by the China Postdoctoral Science Foundation (Postdoctor No. 168033, Grant No. 2016M591094) and Zhangzhou Pien Tze Huang Pharmaceutical Co., Ltd (Grant No. 2015HXFWBHQLSQ-001). The experimental facilities were provided by the College of Nature Conservation's Innovation Laboratory, Beijing Forestry University.

Received: 24 August 2016 Accepted: 23 February 2017

Published online: 04 March 2017

\section{References}

1. Yu-Shan C. Histological observation on musk-secreting scented gland in muskrat. Chin J Zool. 2007;42:91-5.

2. Lu L, Liu S, Li Q, Huang S, Bao L, Sheng X, Han Y, Watanabe G, Taya K, Weng $Q$. Seasonal expression of androgen receptor in scented gland of muskrat (Ondatra zibethicus). Gen Comp Endocrinol. 2014:204:1-7.

3. Lu L, Zhang HL, Lv N, Ma XT, Tian L, Hu X, Liu SQ, Xu MY, Weng Q, Watanabe $G$, Taya K. Immunolocalization of androgen receptor, aromatase cytochrome P450, Estrogen receptor alpha and estrogen receptor beta proteins during the breeding season in scent glands of muskrats (Ondatra zibethicus). Zool Sci. 2011;28:727-32.

4. Dubey AK, Plant TM. A suppression of gonadotropin secretion by cortisol in castrated male rhesus monkeys (Macaca mulatta) mediated by the interruption of hypothalamic gonadotropin-releasing hormone release. Biol Reprod. 1985;33:423-31.

5. Knol BW. Stress and the endocrine hypothalamus-pituitary-testis system: a review. Vet Q. 1991:13:104-14.
6. Keller ET, Ershler WB, Chang C. The androgen receptor: a mediator of diverse responses. Front Biosci. 1996;1:d59-71.

7. McLachlan RI, Wreford NG, O'Donnell L, de Kretser DM, Robertson DM. The endocrine regulation of spermatogenesis: independent roles for testosterone and FSH. J Endocrinol. 1996:148:1-9.

8. Welsh M, Saunders PTK, Atanassova N, Sharpe RM, Smith LB. Androgen action via testicular peritubular myoid cells is essential for male fertility. FASEB J. 2009;23:4218-30

9. Palvimo JJ. The androgen receptor. Mol Cell Endocrinol. 2012;352:1-3.

10. Takeda H, Chodak G, Mutchnik S, Nakamoto T, Chang C. Immunohistochemical localization of androgen receptors with mono- and polyclonal antibodies to androgen receptor. J Endocrinol. 1990;126:17-25.

11. Clark BJ, Wells J, King SR, Stocco DM. The purification, cloning, and expression of a novel luteinizing hormone-induced mitochondrial protein in MA-10 mouse Leydig tumor cells. Characterization of the steroidogenic acute regulatory protein (StAR). J Biol Chem. 1994;269:28314-22.

12. Stocco DM, Clark BJ. Regulation of the acute production of steroids in steroidogenic cells. Endocr Rev. 1996;17:221-44.

13. Simpson ER. Cholesterol side-chain cleavage, cytochrome P450, and the control of steroidogenesis. Mol Cell Endocrinol. 1979:13:213-27.

14. Simard J, Ricketts ML, Gingras S, Soucy P, Feltus FA, Melner MH. Molecular biology of the 3beta-hydroxysteroid dehydrogenase/delta5-delta4 isomerase gene family. Endocr Rev. 2005;26:525-82.

15. Luo L, Chen H, Stocco DM, Zirkin BR. Leydig cell protein synthesis and steroidogenesis in response to acute stimulation by luteinizing hormone in rats. Biol Reprod. 1998;59:263-70.

16. Payne $A H$, Youngblood GL. Regulation of expression of steroidogenic enzymes in Leydig cells. Biol Reprod. 1995;52:217-25.

17. Weng Q, Tsubota T, Dai M, Weng J, Tian Y, Xu M, Watanabe G, Taya K. Immunolocalization of steroidogenic enzymes and their expression during the breeding season in the testes of wild raccoon dogs (Nyctereutes procyonoides). Anim Sci J. 2012;83:535-42.

18. Blottner $\mathrm{S}$, Hingst $\mathrm{O}$, Meyer $\mathrm{HH}$. Seasonal spermatogenesis and testosterone production in roe deer (Capreolus capreolus). J Reprod Fertil. 1996;108:299-305.

19. Johnson L. Seasonal differences in equine spermatocytogenesis. Biol Reprod. 1991;44:284-91.

20. Sheng X, Zhang H, Zhang W, Song M, Zhang M, Li B, Weng Q, Watanabe $G$, Taya K. Seasonal changes in spermatogenesis and immunolocalization of inhibin/activin subunits in the wild male ground squirrel (Citellus dauricus Brandt). J Reprod Dev. 2008;54:460-4

21. Zhang H, Sheng X, Hu X, Li X, Xu H, Zhang M, Li B, Xu M, Weng Q, Zhang $Z$, Taya K. Seasonal changes in spermatogenesis and immunolocalization of cytochrome P450 17 alpha-hydroxylase/c17-20 lyase and cytochrome P450 aromatase in the wild male ground squirrel (Citellus dauricus Brandt). J Reprod Dev. 2010;56:297-302.

22. Altun T, Sarihan E. Effects of freshwater and seawater on growth, total testosterone levels and testis development of tilapias. J Anim Vet Adv. 2008;7:657-62.

23. Strauss A, Hoffmann IE, Vielgrader H, Millesi E. Testis development and testosterone secretion in captive European ground squirrels before, during, and after hibernation. Acta Theriol. 2008;53:47-56.

24. Raucci F, D'Aniello A, Di Fiore MM. Stimulation of androgen production by D-aspartate through the enhancement of StAR, P450scc and 3 beta-HSD mRNA levels in vivo rat testis and in culture of immature rat Leydig cells. Steroids. 2014:84:103-10. 